\title{
Changing Structures and Women's Role as Labor Force
}

I Lena Gonäs'

Professor Emerita, Department of Working Life Science, Karlstad University, SE-651 88 Karlstad, Sweden

Senior Researcher, Department of Insurance Medicine, Karolinska Institutet, SE-171 77

Stockholm, Sweden

I Arja Tyrkkö

Senior Lecturer, Department of Social and Psychological Studies, Karlstad University, SE-651 88 Karlstad, Sweden

\section{ABSTRACT}

The objective of this paper is to analyze changes in the development of women's role as labor force over a 40-year period. This is done by presenting research results that concern the restructuring of the labor market over different time periods. The empirical material is from the 1960s, the heyday of the Swedish model; from the 1980s, the period that economic historians label the third industrial revolution; and from the 1990s, a period labeled the new working life that is covering the reorganization of the public sector.

For the first period results from restructuring in the shipyard industry are presented as well as employment outcomes for single individuals. This industry was male dominated with very few women employed, but regional policy measures were implemented to reach a latent female labor force. The second period is covered by a study of closures and cutbacks in different industries in Sweden during 1982-1983. The proportion of women employed in the industries studied was around one third and employment outcomes had a specific gendered pattern. Women did to a lower extent than men get new permanent jobs. Permanent temporariness was introduced as a concept to describe their labor market situation.

The recession that one decade later hit both female- and male-dominated sectors is illustrated by a study of the relations between labor market attachment, working life, and family conditions. The material comes from a regional research program based on a questionnaire and on register data on incomes from 1990 to 1999. The paper analyzes several areas related to work and outside of work that indicate a gendered pattern of multidimensional subordination and an increased polarization in terms of both gender and class.

In conclusion, the 40 years has been a period of dramatic change in women's situation as labor force. In times of restructuring they often entered into precarious job situations or unemployment. Women's double burden proved remarkably resilient when explaining gender differences in employment and working conditions.

\section{KEY WORDS}

Concept of work / gender relations / labor market position / permanent temporariness / structural change / unpaid work / wage earner / working conditions

${ }^{1}$ E-mail: lena.gonas@kau.se 


\section{Introduction}

his paper discusses the gender division of work against the background of a changing composition of the Swedish industrial structure and the labor market. The ambition is to analyze the transformation of women's role as labor force over a period of 40 years-beginning in the early 1960s-and the dramatic change in women's participation in paid work during this period.

The place of women as a reserve army in manufacturing has been a reality, as well as their role as a buffer in the process where the new technology supersedes the old in more recent years (Humphries 1988). On the other hand, in certain parts of the manufacturing industry, as well as in the development of the public sector, women were an ideal labor force: low paid and already trained (Baude et al. 1987). Slowly women's labor force position has been changing (Rubery and Rafferty 2013). Higher education is now contributing to desegregation processes in the labor market in that highly educated women are entering male-dominated jobs that require high qualifications (Bettio and Verashchagina 2009).

In studies that cover the processes of restructuring and their consequences, questions are often raised concerning what happens to people who are hit by restructuring (Gordus et al. 1981). We will in this article use results from these types of studies to analyze women's position in a changing labor market structure from the 1960s to the 1980s, and will then concentrate on what happened in the 1990s. The paper starts with a theoretical discussion on the gendered divisions of labor and the gender segregation in the labor market drawing among others on the work of Joan Acker (1992, 2006, 2011) and Francine Blau et al. (2013) with reference to class and gender relations in organizations and society. Our empirical material covers different time periods: the 1960s and the heyday of the Swedish model, the 1980s and what economic historians have labeled the third industrial revolution, and last the 1990s and the new working life that is related to the reorganization of the public sector, in line with the periodization put forward by Gonäs and Larsson (2014).

Our aim in this paper is to discuss women's situation as labor force in the different rounds of restructuring over a 40 -year period. The overarching research question is formulated as follows: What role did women play as labor force during different time periods and how was their situation and position connected to the outcomes of the restructuring processes in the different periods?

\section{Gender, class, and the concept of work}

The British economic geographer Doreen Massey (1984) argues that it is in periods of restructuring that conditions are created conducive to changing the established patterns of gender divisions. One persistent problem is the difficulty of linking the analysis on societal and organizational levels to individual levels. When analyzing differences between production and reproduction-goods/capital on the one side and care and service work on the other-the analysis is situated on a societal level. Concepts such as high and low qualified jobs, repetitive work versus autonomous jobs with enhancing skills, high- and low-paid jobs are used for describing the gender division on the organizational level. These divisions of work are characterized by the fact that it is mostly women who 
are found in low-qualified, monotonous, and low-paid jobs, while the description is often made in class-based terms (Acker 2006).

One conclusion from Jane Humphries' work on three rounds of restructuring in the American economy is that the increase in women's labor force participation is double edged (Humphries 1988). American women, like women in most other countries, entered the manufacturing industries in unqualified, low-paid jobs and experienced bad working conditions. In times of restructuring they were made redundant to a great extent and entered into precarious job situations or unemployment. As our examples will show this was also the case in Sweden. Seen from a working life perspective, the contemporary gender division of work, where women still have the responsibility for unpaid work in the household, exploitation is a concept that rather well describes their situation (Jordansson et al. 2011). It is important to discuss an enlarged concept of work in which both paid and unpaid work are taken into consideration. Acker (2011) uses the concept 'encumbered' and 'unencumbered' when discussing the situation of women and men in the labor market. Women are encumbered by their unpaid household work and their responsibility for work related to the family, that is, work that they mainly bear, while men are unencumbered in these aspects.

When Joan Acker came to Sweden in the early 1980s she was surprised that Swedish unions did not use the Law on Co-determination of 1977 (Medbestämmandelagen, MBL) as a means to improve gender equality in the workplace (Acker 1992). Increasing female employment and economic independence for women formed the grounds for active policies on equal opportunities at the workplaces. But the Swedish labor market and society as such remained divided in terms of gender. To understand these contradictions Acker argued that one has to have a historical perspective. The power relations that formed the Swedish labor market model curtailed women's possibilities and limited how far they could go in counteracting their subordination (Acker 1992) According to Acker, two discourses were formed, one being a male discourse, formulated by men for men, with reference to economic growth, productivity, class, and paid work; and a second one on women, children, family, and the arrangements of the welfare state. The male discourse on economy and class reigned supreme in Sweden for 50 years and was established among the social partners, in unions, in business life, and in the political leadership. The discourse on women and the welfare state took place in women's political organizations, in special sections of the unions, in Parliament, in public administration, and in informal women's groups but was clearly overshadowed by the class discourse. Female activists were successful in promoting political issues on day care, parental leave, and separate taxation. They were less successful in changing the gender order in working life, given that matters in this field belonged to the male class-based discourse. Issues on gender have been raised and discussed by women on the political arena, driven by the ideology of equal opportunities and justice, but they met a lot of opposition and counteraction when trying to confront the male-dominated class discourse. Difficulties in combining a labor market career and family obligations have also to been defined, emphasized, and depicted as what they are, namely labor market issues and questions of how work is organized. To address these issues and to equalize the working and labor market conditions for both women and men would ask for commitment from both parties carrying the two discourses. 


\section{Methods of presentation}

When discussing social forces that are generating gender inequality Blau et al. (2006) make a distinction between proximate mechanisms of change and more distal or exterior 'macro-level forces.' Proximate mechanisms are defined as discrimination, internalization, labor force commitment, cultural devaluation. Macro-level forces are economic, organizational, political, and cultural forces. Using macro-level forces as a starting point they discuss changes that are positive seen from a gender equality perspective and countervailing negative mechanisms. Their analysis shows that the most persistent mechanisms shaping gender inequality are different types of discrimination on organizational level and the traditional gender division of reproductive work in the household.

For the discussion of research results concerning the development of women's role as labor force we use a multilayered approach. The societal context at different time periods is used to analyze macro-level forces. Results from different empirical studies conducted by the authors, either separately or together, answer our overarching research questions. We use a multilayered approach to produce a more complete picture, combining information from investigations of macro-level structures with results concerning organizations, groups, and individuals from empirical studies based on different kinds of data or sources (Creswell 2003).

\section{Time periods}

Our empirical material is taken from studies performed during different periods of time, periods which by economic historians are labeled as the second and third industrial revolution (Magnusson 2000). These are periods when Swedish manufacturing industries restructured due to international and global competition and when, in addition, new technology was extensively introduced in the production processes. These were also periods when service sectors grew, in both the private and public sector, when the gender composition of the labor force changed rather dramatically, as well as the distribution of employees over the economic sectors. Figures 1 and 2, respectively, illustrate the development of employment and unemployment for women and men in Sweden from 1961 to 2010 . Women's employment levels increased steadily from the early 1960s until the start of the large recession in 1991. During this recession employment levels dropped for both women and men and have continued on a lower level ever since.

Where unemployment is concerned there has been a development in the opposite direction. Unemployment levels have had a cyclical development from the 1960s until the early 1990s, never reaching over the 4 percent level. Unemployment rose sharply in the beginning of the decade, decreased at the end, and has since the early 2000s varied between 6 and 8 percent for both women and men.

We are using three time periods where we for each period present changes in the production structure, its driving forces, and its consequences for the labor market. For the last of these, we follow the consequences of change until 2001. For the first two periods, the findings are based on case studies, while the third is based on a regional study. 
Figure I: Employment levels for women and men in Sweden $1961-2010$.

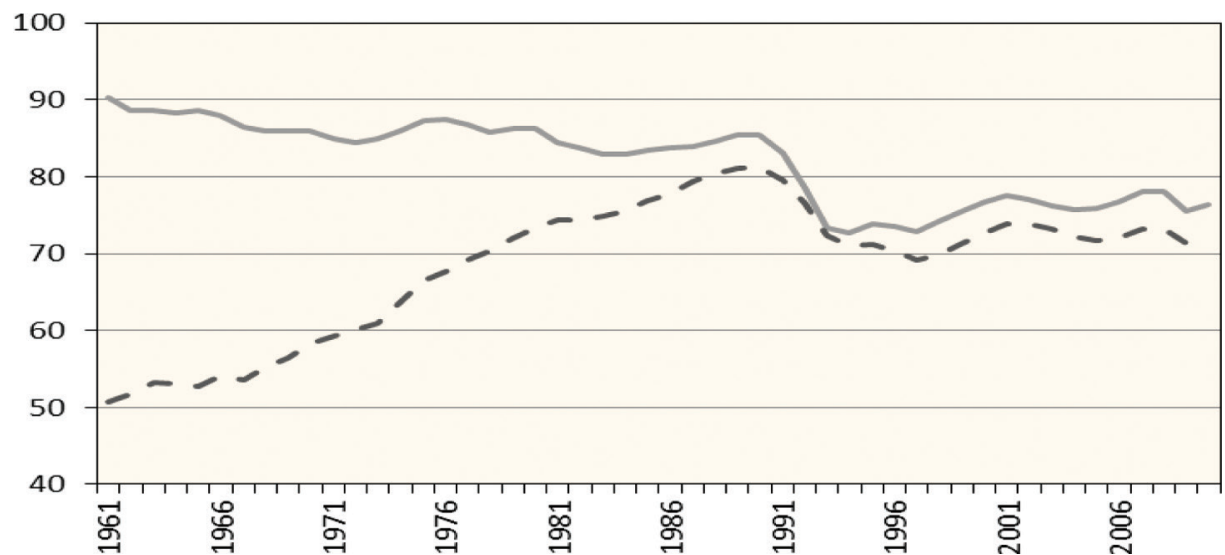

- Men

- Women

Note: In 1987 the Swedish Labour Force Survey (LFS) underwent several changes, including definitions of groups belonging to the labor force. Data before 1987 are thus not fully comparable with the period from 1987 onward. Minor time series breaks can also occur in the period up to 1987.

Source: Statistics Sweden (201 I).

Figure 2: Unemployment levels for women and men in Sweden 1961-2010.

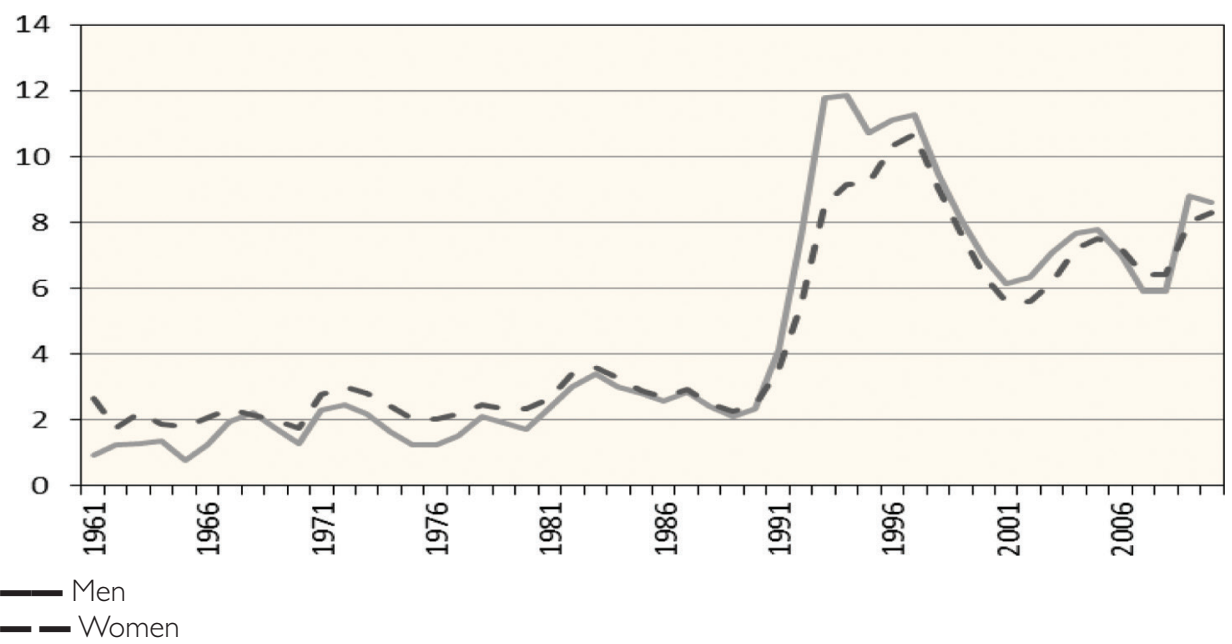

Note: In 1987 the Swedish Labour Force Survey (LFS) underwent several changes, including definitions of groups belonging to the labor force. Data before 1987 are thus not fully comparable with the period from 1987 onward. Minor time series breaks can also occur in the period up to 1987. Source: Statistics Sweden (20 I I). 


\section{The 1960s: The heyday of the Swedish model}

Economic historians define this period as belonging to the second industrial revolution (Magnusson 2000). This phase included restructuring, deindustrialization, and an increasing competition from developing countries in South East Asia. From a Swedish perspective the textile and clothing industries were the first ones to move production abroad, resulting in plant closures and redundancies on a larger scale. Not long after, mining, steel, shipbuilding, paper and pulp, basic industries for Sweden and traditionally male dominated, entered the restructuring phase. At this time a lot of public policy support, labor market policy, and industrial policy measures were used to ease the negative consequences for both the single individual and the local/regional labor markets. Women's position in the labor market was similar to most mid- and northern European countries at that time (Dahlström 1968). The employment rate (the number of employed women in relation to women over 15 years) for Swedish women was quite low until the 1960s (Silenstam 1969). Counted like this, the employment rate for women in the 1930s was around 30 percent, according to the Population Survey (Folk- och bostadsräkningen), and slightly under 90 percent for men in the same age groups, 15 years and above (Silenstam 1969). Although there were some variations between different years, the employment situation for women did not change very much. As can be seen in Figure 1 there is a steady rise in women's employment participation from the mid-1960s. A shortage of labor had opened up for the recruitment of women to the manufacturing industries and also to the service sectors. At the same time political decisions on a separate taxation system for men and women, establishment of day care, and parental leave paved the way for women's entry into the labor market.

\section{The shipbuilding industry and state policies}

When moving to important changes in this period we have chosen a study of the restructuring of the shipbuilding industry in the 1960s (Gonäs 1974) as the first concrete example. It describes the processes of contraction and closure of a shipyard and the involvement of different actors in this process. The objective was to study the consequences for the employees, their families, the local society, and the regional labor market. The outcomes of labor market policy measures for different employees and specifically the selective measures designed for single individuals as well as the government's regional policy were of special interest.

The first crisis of the company occurred in 1962 and the second in 1967, when the company closed down. A questionnaire was sent out to a sample of 382 individuals employed in the company from 1960 to 1967; the response rate was 75 percent. The employees were divided into three groups based on when they left the company. One group consisted of those who left before the first crisis of 1960-61, the second group consisted of those who left during the contraction phase of 1962-65, and the third group consisted of those who left the company under the closing phase 1966-67. The first two periods included a boom period, while the last period was marked by an economic downturn.

To get an insight and overview over the processes, different statistical sources were used to describe the changes in the regional employment structure and the implementation of labor market and regional policy measures. 
The Swedish Labor Market Board (AMS) used the policies implemented in the first crisis up until 1965 as a textbook example of what type of measures should be used in supporting the single individual in the case of job loss. Two years later the Swedish economy was in a deep recession. Age, skill and labor market situation interacted in a way that led to a situation where those who stayed in the company until the closedown had the biggest difficulties to find a new job. The employment agency worked in particular with the employees from the shipyard who met the greatest difficulties in getting a new job, but it could not counteract the negative effects of the economic recession at the time of the closedown of the shipyard.

Low-skilled workers had the highest unemployment levels and the greatest difficulties in getting similar jobs as they had held on the shipyard. Women had not been shipbuilders; they had been working in the office as accountants and clerical workers. They had been very few and in the income distribution among the white collar workers one can see that this occupational group had received between 50 and 60 percent of the income for engineers and technical staff, a fairly stable pattern during the entire period of the study.

As a consequence of the shutdown of traditional industries, the regional labor market experienced a differentiation with new types of manufacturing industries that were moving into the region, industries that did employ women in unskilled manual jobs. Regional policies contributed to this, for example, subsidies for companies to start production in the region. One of the companies that got support by means of regional policies was a telecommunications plant which after some years was bought by a Swedish multinational corporation. The number of jobs that disappeared through the closure of the shipyard was around 600. The regional labor market got less dependent on heavy manufacturing and new employment possibilities were formed for women who were seen as an unexploited labor market reserve.

\section{Selection and economic forces}

The shutdown of the shipyard company happened in the middle of a national economic recession with very few job opportunities, both regionally and nationally. An effect of the business cycle made the situation even worse for those without a job. To this one can add another effect, namely the structural one. The economic demand for labor changed in the manufacturing industries and those who left the company before the shutdown got new jobs relatively easily, while, as mentioned earlier, there was a selection mechanism in that those who had great difficulties in getting a new job contacted the local employment agency. Using the concepts of Blau et al. (2013), we can argue that the selection of skilled workers was a proximate mechanism of change since there was a higher demand for skilled than for unskilled workers who, in their turn, suffered from increased unemployment. Regional employment measures did to a certain extent help to achieve increased employment, but very few of the former shipyard workers gained employment in the new companies.

\section{The 1980s:The third industrial revolution}

This is the period when the consequences of globalization and the third industrial revolution start to be seen on almost every level of society. Employment in manufacturing 
sectors decreased due to at least three factors (Magnusson 2000). Increased internationalization, including world trade and deregulation in the financial sectors, led to a growing international competition. A driving force was the internationalization of the production system and the growth of Newly Industrialized Countries. One more factor was the growth of information technology that revolutionized production techniques in manufacturing. To the third factor Magnusson assigns changes in the production system toward lean production and just in time.

Casting a glance at women's labor force participation rate in the context of ongoing changes, it had in the mid-1980s increased to 80 percent of all women aged 20-64 years. The increase was mainly due to women who working long part-time (20-34 hours a week) and who were employed by a growing public sector.

In this section we refer to results from research projects conducted at the Working Life Centre in Stockholm to illustrate the consequences of restructuring in manufacturing during the 1980s (Gonäs 1990; Gonäs and Westin 1993). In these projects a total of 17 companies were studied, whereof nine were cutbacks and eight closures. They were selected according to certain criteria, such as type of industry, form of restructuring, region, and gender structure of the company. Altogether 3,375 individuals were included in the study, all of them made redundant at the 17 companies. One third of them were women. Labor market histories of the employees were collected for a 2-year period following the redundancy. The companies were selected from the register of companies under notice of dismissal at the National Labor Market Board. Among the companies were the shipyard discussed in our first time period. It had started all over again together with the telecommunications plant that had been established at the time of the closure of the shipyard in the same town. This time the telecommunications plant closed and the shipyard was restructured (Gonäs 1990).

\section{A gendered employment outcome}

Women in our companies were to a large extent employed in so-called unskilled manual jobs of the work organization. This had, of course, consequences both for being able to keep a job in a restructuring situation and finding a new one if the company closed down. Having been a core group member at the plant often led to a better possibility of getting a new permanent position elsewhere (Farber 2005; Gordus et al. 1981; Kletzer 2001).

At the end of the 2-year follow-up period 54 percent of all men and 36 percent of all women were in a permanent job. The women had more periods of unemployment and had been unemployed for a longer time than men; they were also to a greater extent unemployed at the end of the follow-up period. The form of change was important for future possibilities. In cutbacks, male employees were often rehired, meaning that the reemployment level was higher than in shutdowns and that the level of unemployment was lower. Due to that it was to a larger extent their jobs that were primarily reduced in the cutbacks, these patterns were not found for women. One third of the women had left the labor force as a result of cutbacks compared to 13 percent from the closures. We also made an estimation of the probability of getting a permanent job by using a statistical method for modeling classified data (Gonäs and Westin 1993). The results showed that men in every socioeconomic group had a higher proportion of permanent 
employment than women. For men the proportion increased by socioeconomic group, but this did not happen to the same extent for women. Class played a more important role for men than for women in the search for a new job. The gendered nature of sectors in the labor market played a role as well in that women entering the public sector rarely got a permanent job. They became what we labeled a 'reserve army' to the public sector.

\section{Precarification and permanent temporariness}

In these processes of change, that is, cutbacks and closures, many young and middle-aged women were employed in temporary jobs, became unemployed, or relied on labor market policy measures, such as education or training. We have used the concept 'permanent temporariness' to name this labor market position of always being in a temporary situation, a situation quite common for many women. In some of our cases the women went from being a buffer labor force in the telecommunications industry to a reserve army in the public sector. Our longitudinal analysis showed that for both women and men the participation in a labor market policy measure, or having a temporary job, did not increase their probability of getting a permanent job. Individuals in these positions had the lowest transition rates to a permanent job (Gonäs and Westin 1993).

\section{0 s restructuring - and the new working life}

In the first half of the 1990s, in Sweden as in many other countries, a deep recession caused the highest unemployment levels since the depression of the 1930s. In Sweden the building and construction industries were the first to be hit by redundancies, followed by the manufacturing industries. In total over 300,000 jobs disappeared until the mid-1990s in these sectors. The service sectors too reduced employment and employment decreased with around 200,000 jobs. The result was that employment levels for both women and men sunk dramatically and, naturally, unemployment levels rose (see Figure 2). A whole series of institutional and economic changes took place, resulting in these high unemployment levels (SCB 2010). From experience of previous recessions, we are aware that many of those who lose their jobs during short-term recessions risk finding themselves in a situation of permanent exclusion (Farber 2005, 2008; Kletzer 2001). Drawing on experiences of crises and structural changes in Sweden, it can be said that the public sector underwent changes during the 1990s that were at least as dramatic as those within the manufacturing sector (Gonäs 2006; Holmlund and Storrie 2002; Lundborg 2001; SCB 2010). One important result and lesson from the 1990s was that women did not revert to being housewives when they lost their jobs in this recession (Palme et al. 2002). Cutbacks in the 1990s in the female-dominated sector of the labor market, such as in health and care, were a new phenomenon, but it did not lead to women leaving the labor market to a higher degree than men. Another result of the crisis was that the tendency toward a reduction in class differences that could be seen for earlier decades halted, meaning that class differences were considerably greater at the end than at the beginning of the decade (Palme et al. 2002). 


\section{Research design, method, and material}

In this section we refer to the research project Gender and Work at the National Institute for Working Life in Stockholm (see Gonäs 2005, 2008). With focus on a specific geographical region, a population-based questionnaire survey, covering a random sample of 10,000 persons, was performed in 2001. The sample did correspond to 10 percent of the population aged 20-64 years. The questionnaire included a large number of questions covering areas such as labor market position, physical and psychosocial work conditions, unpaid work load, education, health, family situation, lifestyle, etc. When possible, well-validated instruments were used. Great efforts were made to include gender-relevant aspects. Register data from the LOUISE-database at Statistics Sweden (SCB 1998) were linked to each of the 10,000 individuals in the sample, covering information on income and workplace and on education and labor market position for the years 1990 to 1999. The response rate was around 50 percent (55 per cent for women and 45 per cent for men). The final material consisted of responses from 4,965 persons, whereof 2,756 were women. More women than men answered the questionnaire, more of the older than the younger ones and more of the well educated than the lower educated (Gonäs 2005). Thanks to having access to register data for the whole population we had good control over the drop-outs or non-respondents. We were able to take this into account in our analyses and have made extensive analyses of non-respondents (Bildt and Karlqvist 2004; Nyfjäll and Bildt 2004).

\section{An explorative stepwise analysis}

Due to our ambition to relate labor market attachment to different aspects at work and to other conditions of life we chose to base the analyses on a large number of variables. We began the analysis by constructing a classification of employment status for each individual for every year between 1990 and 1999. Our approach was to study individual mobility patterns and transition rates between different labor market positions over time. There are different methods being used in analyzing labor market transition patterns, for example, Ashton and Sung (1992) who interviewed employers and young adults about their career paths, Burchell (1993) who used SCELI (Social Change and Economic Life Initiative) data for the analysis of job changes, Gonäs (1990) using longitudinal data for people who had lost their jobs due to having been involved in plant closures or restructuring processes in manufacturing industries, and Korpi and Levin (2001) using a Nordic data set for individuals in the age span of 25 to 54 years. Transition chains for each individual in our sample were constructed. These chains were based on the classification of the duration of their labor market positions over the period of 1990 to 1999 , for example, the single labor market status that was most frequent during the period. This measure was put in relation to the labor market status that the single individual had reported in the questionnaire for 2001. We thereby had two measurements for the labor market position for the single individual, one measure for the historical development from 1990 to 1999 and one for the position in 2001. Both measures have to be understood as summarizing measures. 
We then formulated a number of logistic regressions to discover relationships between background variables, labor market positions, working conditions, and family responsibilities. In the analysis we applied a stepwise model, but we did not eliminate variables from the models. Thus, in the final step all variables from previous steps are included as explanatory variables. The analysis was explorative in its character.

Outcomes of the two measures of labor market positions are presented in the first step. Labor market positions are explained by gender and age in these calculations. In the second step, various working conditions for 2001 were analyzed. The starting point was to define which background variables, in total eight including labor market status during the period that would be related to different working condition variables. In the third step we analyzed family responsibilities using three variables. These were put in relation to the variables relating to individual background and to working conditions.

\section{Labor market position 200 I}

Labor market attachment was an important concept in our points of departure. An individual with a stable position in the labor market has a higher possibility of having good working conditions than a person who has temporary and unstable employment (Wikman 2005). The picture is mixed and the increase of temporary contracts during the last decades indicates that also jobs with good working conditions can be of a temporary character (Virtanen et al. 2006). A definition of labor market attachment can be based on what type of employment the single individual has (permanent or temporary), number of hours, length of employment, unemployment or other reasons for not being in employment, and the duration of these different types of activities over a certain time period (Gartell 2010; Zijl et al. 2004).

Our results concerning labor market attachment and a number of background factors are presented in Table 1. The analysis shows that besides the labor market history of a person, gender had a high explanatory value for individual labor market positions in 2001. To be a young woman with a weak attachment to the labor market during the 1990s contributed highly to explaining exclusion from the labor market in 2001 (i.e., being in the labor market position defined as 'others'). ${ }^{1}$ Most decisive was the labor market position during the 1990s. If the individual had been employed during the biggest part of that period, this positively affected the possibility for the individual of being employed in 2001. Of those who belonged to the category 'others' in 2001, close to 55 percent had belonged to this group during the period of 1990 to 1999. In a similar way, of those who were employed in 2001 more than 88 percent had been so during the period 1990 to 1999 . These categories summarize the employment status for single individuals over a decade and they are of course very crude. But it gives at any rate an estimation of the stability and instability of their labor market attachment. For those who did not have a stable labor market attachment, we saw the development of an agerelated alternative support system. Education was an alternative system for the young age groups, while sickness and pre-pension benefits have been acting as an alternative support system for the middle aged until they reached their regular pension age, which was 65 year. 







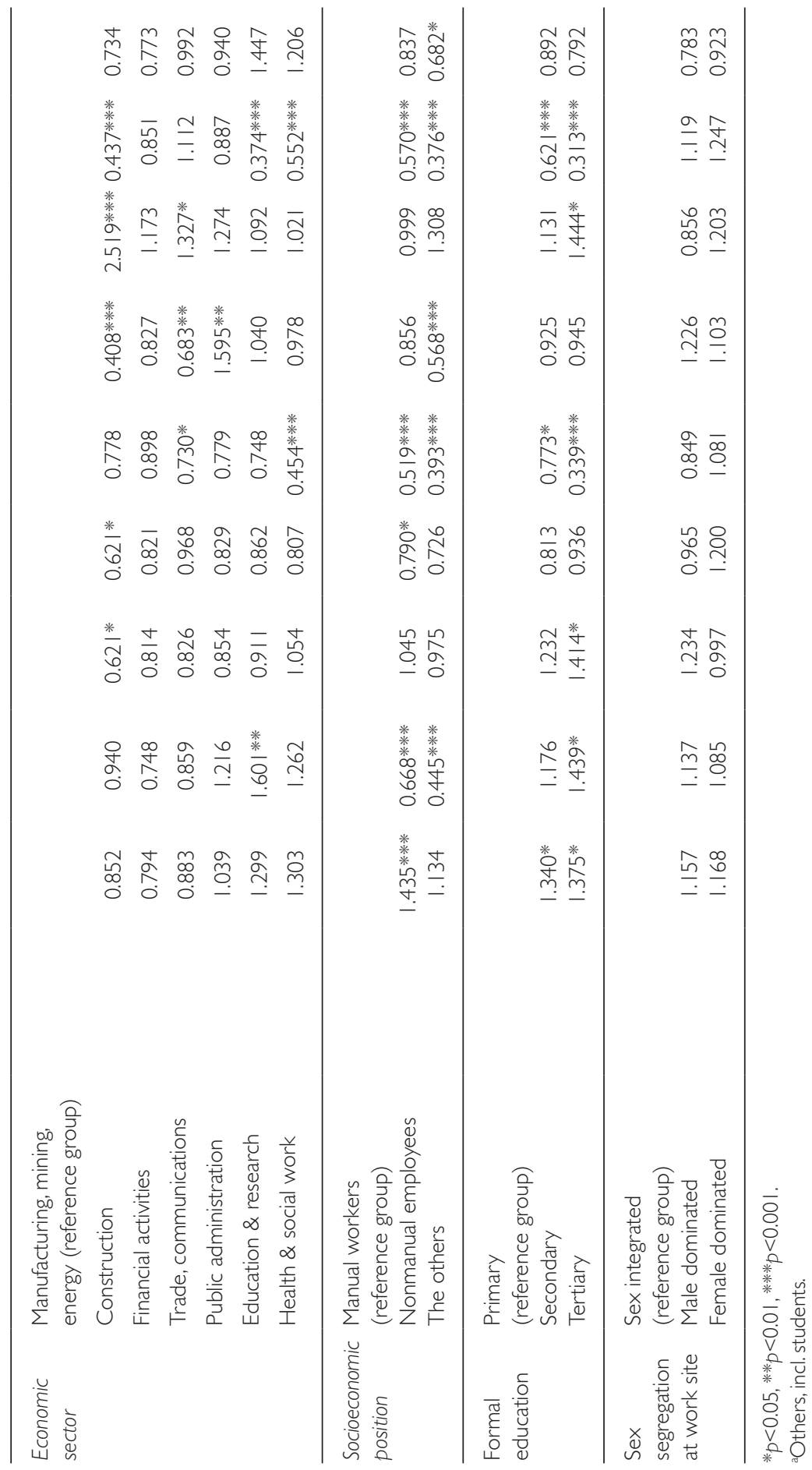




\section{Labor market attachment and working conditions}

The trends in Swedish working conditions were mostly negative in the 1990s. The development was however different for various areas of the labor market. Several studies pointed to the fact that the labor market was in a process of changes, implying for example a more marked exposure to competition, also stressing organizational factors such as more limited staffing, something that did increase the workload for many employees (Burchell et al. 2007; Härenstam et al. 2000; Marklund and Härenstam 2010). The cuts were particularly tangible in the public sector, a fact that did reflect in a more extended increase of the workload for women as compared to men, who were largely employed in the private sector (Gustafsson 2005). The studies of the Welfare Commission (Palme et al. 2003) demonstrate clearly that the deterioration of the psychosocial work environment was strongest in the welfare service sector (school, health care and care services) as well as in a number of other service sectors where women were overrepresented. An increased work pace, combined with a lack of control, made it increasingly difficult to cope with conditions in working life (Eurofound 2005; Wikman 2005). As stated by Palme et al. (2003: 21-22): 'Not least, there was a substantial rise in the numbers of jobs with high physical demands and a low degree of autonomy, i.e. negative stress.'

In the next step (see Table 1) factors related to working conditions were entered into the analysis as dependent variables. The gender difference that we found with regard to labor market situation drops to well below significance level when working conditions are concerned (with the exception of the level of control). Instead, it is gender segregation that appears to explain differences in many aspects of working conditions. We thus found that the gender dimension was put into the context of gender segregation in economic sectors, in education and socioeconomic positions, whereas clear associations to gender segregation at the work site were not observed. The results show that a higher risk for increasing demands was significantly associated with the situation of non-manual employees. For those working in education and research there was a greater risk for a decrease in positive outcomes or benefits from the job. In the construction sector and in trade and communications there was a significantly higher risk for high demands in work tasks.

\section{Labor market, working conditions, and family situation}

As illustrated in Figure 1, employment rates for women and men were quite similar around 1991 and even unemployment rates were quite similar. Yet there were still large differences between women and men in qualitative terms. Time allocation studies showed that women and men worked just as much, but did distribute their time differently between paid and unpaid work (SCB 2003). Around one third of all employed women in Sweden were still working part-time. Seen from a life course perspective, women and men start out with the same pattern of working hours, although in different sectors of the labor market. It is only when they have their first children that patterns divert (Bernhardt et al. 2008).

In Table 2 we present an analysis relating to labor market position, working and family conditions, and a number of background factors. Family conditions (unpaid work conditions) are dependent variables. A variable that stood out very clearly was 
Table 2: Binary logistic regression analysis concerning labor market position, working and family conditions, and a number of background factors

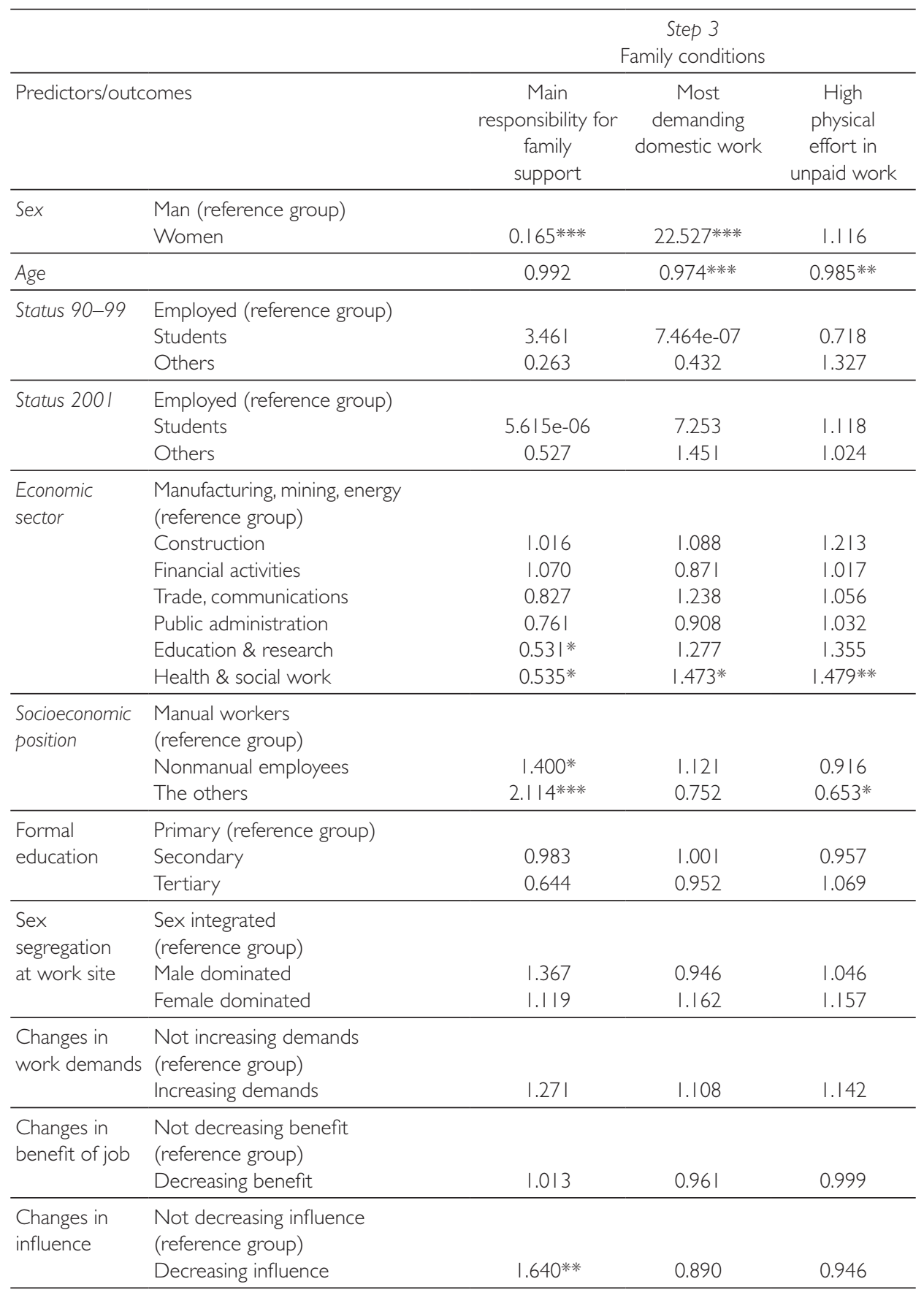


Table 2: (continued) Binary logistic regression analysis concerning labor market position, working and familyconditions, and a number of background factors.

\begin{tabular}{|c|c|c|c|c|}
\hline \multirow{2}{*}{\multicolumn{2}{|c|}{ Predictors/outcomes }} & \multicolumn{3}{|c|}{$\begin{array}{l}\text { Step } 3 \\
\text { Family conditions }\end{array}$} \\
\hline & & $\begin{array}{c}\text { Main } \\
\text { responsibility for } \\
\text { family } \\
\text { support }\end{array}$ & $\begin{array}{c}\text { Most } \\
\text { demanding } \\
\text { domestic work }\end{array}$ & $\begin{array}{c}\text { High } \\
\text { physical } \\
\text { effort in } \\
\text { unpaid work }\end{array}$ \\
\hline $\begin{array}{l}\text { Level of } \\
\text { comfort }\end{array}$ & $\begin{array}{l}\text { High comfort (reference group) } \\
\text { Low comfort }\end{array}$ & 0.729 & 1.192 & 1.175 \\
\hline Insecurity & $\begin{array}{l}\text { Low insecurity (reference group) } \\
\text { High insecurity }\end{array}$ & 1.025 & 0.991 & $1.256 *$ \\
\hline Expectations & $\begin{array}{l}\text { High expectations (reference group) } \\
\text { Low expectations }\end{array}$ & 0.863 & 1.033 & 1.250* \\
\hline Demands & $\begin{array}{l}\text { Low demands (reference group) } \\
\text { High demands }\end{array}$ & 1.042 & $\left.1.34\right|^{*}$ & 1.482米米 \\
\hline Control & $\begin{array}{l}\text { High control (reference group) } \\
\text { Low control }\end{array}$ & 0.974 & $1.362 *$ & 1.087 \\
\hline Social support & $\begin{array}{l}\text { Low social support } \\
\text { (reference group) } \\
\text { High social support }\end{array}$ & 0.968 & 0.939 & 1.086 \\
\hline
\end{tabular}

* $p<0.05$, *** $p<0.01$, **** $p<0.001$.

'most demanding household work,' which indicates that traditional gender roles are still very strong. Women had a 22 times higher probability than men of having this type of household work in the family. Since the coefficient for age is positive, the probability of being most responsible for demanding domestic work increases with age and the same is true for high physical effort in unpaid work. Even the employment sector was of importance. Respondents who were working in health-related jobs and social work, that is, female-dominated sectors, had a higher risk for being responsible for the most demanding domestic work and suffered from higher physical effort in unpaid work. The reverse result was found in relation to main responsibility for family support. Persons who were working in the fields of education/research and in health/social work had a lower risk for carrying the main responsibility for family support than the reference group, namely those employed in male-dominated sectors such as manufacturing, mining, and energy.

\section{Gendered pattern of multidimensional subordination and increased polarization}

We have found considerable support for the proposition that the recession in the 1990s contributed to a precarification process of women's employment in the early 2000s. This is specifically true for those who had had a weak labor market attachment during the previous decade. This finding does not support Crompton's (2006) argument that women's position in the labor market is more a modification of earlier situations than a 
stable change. What we can see is support for increased polarization between those with a weak and those with a strong position in the labor market.

Working conditions seem to have developed along different lines depending on structural factors. Individuals that were experiencing an insecure position in relation to the labor market in 2001 had also working conditions that were unsatisfactory. And again we can find signs of a process of polarization and differences between employees related to degree of labor market attachment and stability in labor market position.

A higher risk for carrying the main responsibility for support of the family was found for non-manual employees as well as for other types of occupation. These results seem to indicate a relationship between the gender structure of the employment sector and family conditions. Employees in female-dominated economic sectors had a high risk of having the most demanding domestic work as well as a high risk of high physical effort in unpaid work, while at the same time having a low risk of being the main provider of income for the family.

\section{A 40-year perspective}

Our examples from the two earlier periods will now be compared and seen in relation to our study of the effects of the recession in the 1990s. In the first two stages, women's role as labor force was under formation. We can witness a quick increase in the employment rate for women, but at the same time we can show what it means for there to be two types of labor force, that is, the unencumbered and the encumbered worker. Belonging to the latter one implies, as we have shown, a high risk of double exploitation, both in paid and unpaid work. From having been a latent part of the labor force, as illustrated by our first example, women reached almost the same employment levels as men in the early 1990s. The recession that hit the economy shortly afterward led to a sharp decrease in employment levels for both women and men, causing a clear gender difference that continued into the 2000s.

In the process of restructuring and reorganizing the public sector, gendered contracts are being contested. Ambitions to cut budget deficits and the public debt, in Sweden and in most other countries, did lead to reductions in welfare provisions and in public sector employment. The dual role of the welfare state has been very important for many women, not least in the Scandinavian welfare states. As the level of both welfare provisions and employment fell, there was a risk that women suffered on both accounts. What we have seen, when looking back over a 40 -year period of restructuring, is that women's position in the restructuring process has changed. Their role as a reserve army does not fit anymore. But the process of precarification of the position of women-this relatively more recent form of employment-that we first saw in the response to the cutbacks in the telecommunications industry in the 1980s, has emerged as an important process 30 years later: 'Whether cause or effect, women's growing labour market role has coincided with the growth of the precariat' (Standing 2011: 60).

The results that we are presenting are, as usual, not straightforward. With regard to the sharp increase in absence due to illness, we felt that it was important to try to understand or to find out the reasons behind this development. As already discussed by academic women 60 years ago, women's double burden still stands out as very important when explaining gender differences in employment and working conditions (Baude 1992). 


\section{References}

Acker, J. (1992) 'Reformer och kvinnor i den framtida välfärdsstaten' ('Reforms and Women and the Future of the Welfare State'). In: J. Acker et al. Kvinnors och mäns liv och arbete. (Women's and Men's Life and Work). Stockholm: SNS Förlag, pp. 279-309.

Acker, J. (2006) Class Questions. Feminist Answers. New York: Rowman \& Littlewood.

Acker, J. (2011) 'Why Such Persistent Gender Gaps in Working Life? A Short History of Theorizing Gender Inequality in Work'. Paper prepared for the Symposium on Conditions for Egalitarian and Sustainable Growth, Karlstad University, Sept. 30, 2011.

Ashton, D.N. \& Sung, J. (1992) 'The Determinants of Labour Market Transitions: An Exploration of Contrasting Approaches'. Work, Employment \& Society 6(1):1-21.

Baude, A. et al. (1987) Kvinnoarbetsliv (Women's Working Life). Stockholm: Arbetslivscentrum.

Baude, A. (ed.) (1992) Visionen om jämställdhet (The Visions of Equal Opportunity). Stockholm: SNS Förlag.

Bernhardt, E., Noack, T. \& Hovde, T. (2008) 'Shared Housework in Norway and Sweden: Advancing the Gender Revolution'. Journal of European Social Policy 18(3):275-288.

Bettio, F. \& Verashchagina, A. (2009) 'Gender Segregation in the Labour Market: Root Causes, Implications and Policy Responses in the EU'. EU Expert Group on Gender and Employment (EGGE). Luxembourg: European Commission.

Bildt, C. \& Karlqvist, L. (2004) 'Kvinnor och män i Östergötland. Arbete, fritid och hälsa' (Women and Men in Östergötland: Work, Leisure and Health). Working paper 2004:13. Stockholm: Arbetslivsinstitutet.

Blau, F.D., Brinton, M.C. \& Grusky, D.B. (eds.) (2006) The Declining Significance of Gender. New York: Russel Sage.

Blau, F.D., Brummund, P. \& Yung-Hsu Liu, A. (2013) 'Trends in Occupational Segregation by Gender 1970-2009: Adjusting for the Impact of Changes in the Occupational Coding System'. Demography 50:471-492.

Burchell, B. (1993) 'A New Way of Analyzing Labour Market Flows Using History Data'. Work, Employment and Society 7(2):237-258.

Burchell, B., Fagan, C., O’Brien, C. \& Smith, M. (2007) 'Working Conditions in the European Union: The Gender Perspective'. European Foundation for the Improvement of Living and Working Conditions. http://www.eurofound.europa.eu/pubdocs/2007/108/en/1/ ef07108en.pdf [Available 02/01/2009].

Creswell, J.W. (2003) Research Design: Qualitative, Quantitative and Mixed Methods Approaches. Thousand Oaks, CA: Sage.

Crompton, R. (2006) 'Employment, Flexible Working and the Family'. In: L. Gonäs \& J. Ch. Karlsson (eds.) Gender Segregation. Divisions of Work in Post-Industrial Welfare States. Aldershot: Ashgate, pp. 127-147.

Dahlström, E. (1968) 'Analys av kön och familj' ('Analysis of Gender Role Debate and Family'). In: A. Baude et al. (eds.) Kvinnors liv och arbete (Women's Life and Work). Stockholm: SNS Förlag, pp. 18-53.

Eurofound (2005) Fourth European Working Conditions Survey. http://www.eurofound.europa.eu/surveys/ewcs/2005/ [Available 07/02/2011].

Farber, H. (2005) 'What Do We Know about the Job Loss in the Unites States?' Working Paper No 498. Princeton: Industrial Relations Section, University of Princeton.

Farber, H. (2008) 'Employment Insecurity: The Decline in Worker-Firm Attachment in the United States'. Working Paper No 530. Princeton: Industrial Relations Section, University of Princeton.

Gartell, M. (2010) The Collage-to-Work Transition during the 1990s. Evidence from Sweden. Stockholm: Institute for Future Studies 2010:3. 
Gonäs, L. (1974) Företagsnedläggning och arbetsmarknadspolitik. Geografiska Regionstudier nr 10. Kulturgeografiska institutionen. Uppsala: Uppsala Universitet.

Gonäs, L. (1990) 'Labour Market Adjustments to Structural Change in Sweden.' In: E. Appelbaum \& R. Schettkat (eds.). Labour Market Adjustments to Structural Change and Technological Progress. New York: Praeger, pp. 180-203.

Gonäs, L. (ed.) (2005) På gränsen till genombrott? Om det könsuppdelade arbetslivet. Stockholm: Agora.

Gonäs, L. (2006) 'Gendered Divisions of Work-A Multilevel Approach'. In: L. Gonäs \& J. Ch. Karlsson (eds.) (2006) Gender Segregation. Ashgate, pp. 29-45.

Gonäs, L. (2008) Arbetsmarknadskarriär, arbetsvillkor och hälsa. Karlstad: Karlstad University Studies, 2008:2.

Gonäs, L. \& Larsson, P. (2014) 'Employment Regimes and Personnel Work in Sweden' In: Bruce E. Kaufman (ed.). The Development of Human Resource Management across Nations. Cheltenham: Edward Elgar, pp. 410-436.

Gonäs, L. \& Westin, H. (1993) 'Industrial Restructuring and Gendered Labour Market Processes'. Economic and Industrial Democracy 14: 423-457.

Gordus, J.P., Jarley, P. \& Ferman, L. (1981) 'Plant Closings and Economic Dislocation'. Kalamazoo: Upjohn Institute for Employment Research, University of Michigan.

Gustafsson, R.A. (2005) 'The Welfare of the Welfare Services'. In: R.A. Gustafsson \& I. Lundberg (eds.) Worklife and Health in Sweden 2004. Stockholm: National Institute for Working Life \& Swedish Work Environment Authority, pp 271-296.

Holmlund, B. \& Storrie, D. (2002) 'Temporary Work in Turbulent Times: The Swedish Experience'. Working Paper 2002:1, Department of Economics, Uppsala University.

Humphries, J. (1988) 'Women's Employment in Restructuring America: The Changing Experience of Women in Three Recessions'. In: J. Rubery (ed.) Women and Recession. London: Routledge \& Kegan Paul, pp. 15-47.

Härenstam, A., Rydbeck, A., Johansson, K., Karlqvist, M. \& Wiklund, P. (2000) 'Work Life and Organizational Changes and How They Are Perceived by the Employees'. In: K. Isaksson, C. Hogstedt, C. Eriksson \& T. Theorell (eds.) Health Effects of the New Labour Market. New York: Kluwer Academic/Plenum Publishers, pp. 105-117.

Jordansson, B., Holth, L. \& Gonäs, L. (2011) 'Genusarbetsdelning-exploatering av kvinnors arbetskraft' ('Gender Divisions of Work-Exploitation of Women's Labour Force'). In: G. Gillberg, T. Bergqvist \& L. Ivarsson (eds.) Arbete: passion och exploatering (Work: Passion and Exploitation). Arbetsliv $i$ omvandling (Work Life in Transition) 03/2011. Växjö: Linneuniversitetet, pp. 35-49.

Kletzer, L.G. (2001) Job Loss from Imports; Measuring the Loss. Washington, DC: The Institute for International Economics.

Korpi, T. \& Levin, H. (2001) 'Precarious Footing: Temporary Employment as a Stepping Stone Out of Unemployment in Sweden'. Work, Employment \& Society 15(1): $127-148$.

Lundborg, P. (2001) 'Vilka förlorade jobbet under 1990-talet?' ('Who lost the jobs during the 1990s?') In: J. Fritzell (ed.) Välfärdens förutsättningar. Arbetsmarknad, demografi och segregation (The Conditions for the Welfare State. Labor Market, Demography and Segregation). SOU 2000:37. Stockholm: Fritzes, pp. 11-50.

Magnusson, L. (2000) Den tredje industriella revolutionen (The Third Industrial Revolution). Stockholm: Prisma and Arbetslivsinstitutet.

Marklund, S. \& Härenstam, A. (eds.) (2010) 'The Dynamics of Organizations and Healthy Work.' Work Life in Transition 2010:05. Kalmar \& Växjö: Linnéuniversitet.

Massey, D. (1984) 'Spatial Divisions of Labour. Social Structures and the Geography of production.' London: Macmillan Press Ltd. 
Nyfjäll, M. \& Bildt, C. (2004) Treatment of Nonresponse in the Survey 'Work and Health for Women and Men' Conducted by National Institute for Working Life in Sweden'. Working paper. Stockholm: Arbetslivsinstitutet.

Palme, J., Bergmark, A., Backman, O., Estrada, F., Fritzell, J., Lundberg, O., Sjöberg, O. \& Szebehely, M. (2002) 'Welfare Trends in Sweden: Balancing the Books for the 1990s'. Journal of Social Policy 12:329-346.

Palme, J., Bergmark, Å., Backman, O., Estrada, F., Fritzell, J., Lundberg, O., Sjöberg, O., Sommestad, L. \& Szebehely, M. (2003) A Welfare Balance Sheet for the 1990s. Final Report of the Swedish Welfare Commission, Scandinavian Journal of Public Health, Supplement 60.

Rubery, J. \& Rafferty, A. (2013) 'Women and Recession Revisited'. Work, Employment \& Society 27(3):414-432.

SCB (1998) LOUISE. En Longitudinell databas för utbildning, inkomst och sysselsättning. Stockholm (A Longitudinal Database for Education, Income and Employment). Stockholm: Statistics Sweden.

SCB (2003) Tid för vardagsliv. Kvinnors och mäns tidsanvändning 1990/91 och 2000/01 (Time for the Daily Life. Time Use Studies of Women and Men 1990/91 and 2000/01) Rapport 99. Levnadsförhållanden (Studies of Living Conditions). Stockholm: Statistics Sweden.

SCB (2010) AM 11. SM 1003. Hur två kriser påverkade arbetsmarknaden. (How Two Economic Crises Affected the Swedish Labor Market). Stockholm: Statistics Sweden.

Silenstam, P. (1969) Arbetskraftsutbudets utveckling i Sverige 1870-1965. (The Development of the Labor Force in Sweden 1870-1965). Stockholm: IUI.

Standing, G. (2011) The Precariat. The New Dangerous Class. London: Bloomsbury.

Statistics Sweden (2011) Arbetsmarknaden under 50 år-några karaktäristiska drag. Statistiknyheter från SCB. Nr 2011: 254, Stockholm: SCB. http://www.scb.se/sv_/Hitta-statistik/ Statistik-efter-amne/Arbetsmarknad/Arbetskraftsundersokningar/Arbetskraftsundersokningarna-AKU/23265/23272/Behallare-for-Press/Arbetskraftsundersokningarna-AKU/

Wikman, A. (2005) 'Indicators of Changed Working Conditions.' In: R.Å. Gustafsson \& I. Lundberg (eds.) Worklife and Health in Sweden 2004. Stockholm: National Institute for Working Life \& Swedish Work Environment Authority, pp. 39-77.

Virtanen, M., Kivimäki, M., Vahtera, J., Elovainio, M., Sund, R., Virtanen, P. \& Ferrie, J.E. (2006) 'Sickness Absence as a Risk Factor for Job Termination, Unemployment, and Disability Pension among Temporary and Permanent Employees'. Occupational and Environmental Medicine 63(3):212-217.

Zijl, M., van den Berg, G. \& Heyma, A. (2004) 'Stepping Stones for the Unemployed: The Effect of Temporary Jobs on the Duration of Regular Work'. Working paper 2004:19. IFAU, Uppsala University.

\section{End note}

1 Students were also included in this group. 